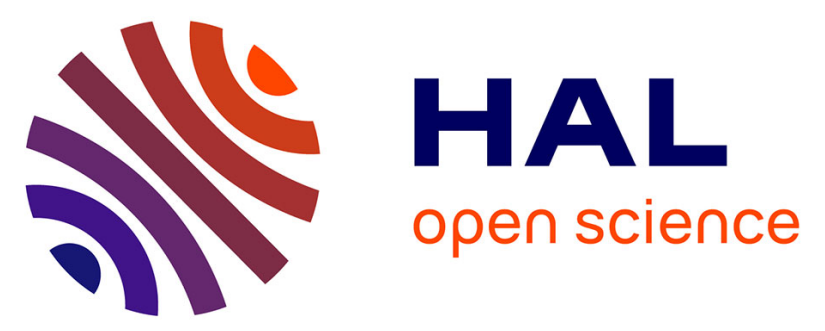

\title{
Hydraulic interactions between fractures and bedding planes in a carbonate aquifer studied by means of experimentally induced water-table fluctuations (Coaraze experimental site, southeastern France)
}

\author{
A. Charmoille, Stéphane Binet, C. Bertrand, Y. Guglielmi, J. Mudry
}

\section{To cite this version:}

A. Charmoille, Stéphane Binet, C. Bertrand, Y. Guglielmi, J. Mudry. Hydraulic interactions between fractures and bedding planes in a carbonate aquifer studied by means of experimentally induced watertable fluctuations (Coaraze experimental site, southeastern France). Hydrogeology Journal, 2009, 17 (7), pp.1607-1616. 10.1007/s10040-009-0470-y · insu-00376151

HAL Id: insu-00376151

https://hal-insu.archives-ouvertes.fr/insu-00376151

Submitted on 16 Apr 2009

HAL is a multi-disciplinary open access archive for the deposit and dissemination of scientific research documents, whether they are published or not. The documents may come from teaching and research institutions in France or abroad, or from public or private research centers.
L'archive ouverte pluridisciplinaire HAL, est destinée au dépôt et à la diffusion de documents scientifiques de niveau recherche, publiés ou non, émanant des établissements d'enseignement et de recherche français ou étrangers, des laboratoires publics ou privés. 
Hydraulic interactions between fractures and bedding planes in a carbonate aquifer studied by means of experimentally induced water-table fluctuations (Coaraze experimental site, southeastern France)

A. CHARMOILLE ${ }^{1}$, S. BINET ${ }^{2}$, C. BERTRAND ${ }^{3}$, Y. GUGLIELMI ${ }^{4}$, J. MUDRY ${ }^{3}$

${ }^{1}$ INERIS, Parc Technologique ALATA F-60550 Verneuil-en-Halatte

${ }^{2}$ Université d'Orléans, CNRS/INSU, Université François Rabelais - Tours

Institut des Sciences de la Terre d'Orléans - UMR 6113

1A, rue de la Férollerie 45071 Orléans cedex

${ }^{3}$ Université de Franche-Comté, CNRS/INSU, Chrono-Environement UMR 6249, 16 route de Gray, F-25030

Besançon.

${ }^{4}$ Université de Nice Sophia Antipolis, CNRS/INSU, Geosciences Azur UMR 6526, 250 rue A. Einstein, F06560, Valbonne.

Corresponding author: stephane.binet@univ-orleans.fr 


\begin{abstract}
.
In aquifers with variable permeability, the water exchanges between high and low permeability regions are controlled by the hydraulic head gradient. Past studies have addressed this problem mainly considering steadystate hydraulic conditions. To study such exchanges during water-table fluctuations, a spring was equipped with a water-gate that creates 10-meter artificial fluctuations of the water table. The water exchanges are discussed with respect to hydrochemical and pressure measurements in the groundwater. With successive water-table fluctuations the mineralization and $\mathrm{pH}$ decrease, but the bicarbonate content increases in response to carbon dioxide dissolution. At this scale of single fractures and surroundings, the hydrochemistry allows water flows from low or high permeability discontinuities to be discriminated. During hydraulic head fluctuations, the waters from low and high permeability discontinuities become mixed. During water-table rise, the low-permeability matrix contributed to the refilling of the permeable faults and to the mixing of the waters. Dynamic flows in the opposite direction to the hydraulic gradient can expel mineralized water, pushing it towards permeable discontinuities. This mechanism could be the cause of the peak in the mineralisation recorded in some karst springs at the start of flood events.
\end{abstract}

Keywords: Karst, hydrogeochemistry, fractured rocks, hydraulic properties, France 


\section{Introduction}

In fractured aquifers that include a low-permeability rock bulk, the main water flow takes place in the network of fractures (Rutqvist 1995). The flow in the fractures is faster than the flow through the rock bulk (Hinds et al. 2003). In such fractured aquifers, the fracturing induces a significant permeability contrast. This characteristic is emphasized in karst systems where some flow paths are extremely developed and form channels or conduits with very high hydraulic conductivities.

Regarding storage capacity, with the use of a four-component mixing model, Lee and Krothe (2003) showed that the total discharge at a spring is a mixture of water from drains, soil, and epikarstic and low-permeability features. Maloszewski et al. (2002) showed that the volume stored in the karst channels is very small (less than $1 \%$ ), and suggested that porosity measurements in low-permeability rock are needed. All these results highlight the major role of the permeable conduits as the water transfer compartment and the important role of the lowpermeability matrix as the water storage compartment in karst aquifer systems (Lee and Krothe 2003).

To predict the spring flow, several authors (Jeannin and Grasso 1995; Guglielmi and Mudry 200, Martin and Dean 2001) studied the water exchanges between the low-permeability matrix and conduits. They showed a reversible relationship related to hydraulic head gradient: low-permeability matrices discharge water to conduits, and conduits discharge water to low-permeability matrices. These studies were done at the aquifer scale and do not address the water mix during transient hydraulic heads. Thus an experiment was proposed, taking place at a sublocal scale, as defined by Kiraly (1969), Teutsch and Sauter (1991), Sauter (1992) and White (2002) (Fig.1) to study the water exchanges between drains and low permeability matrices under transient hydraulic heads.

The purpose of the experiment performed on the natural test site of the Coaraze spring, in the southern Alps, France, is to define the precise relationships between the permeable fractures and low-permeability matrices under experimentally induce water-table fluctuations. The experiment was performed in a fractured carbonate aquifer. At this experimental site, different water-table fluctuations (from 0 to 10 meters) are generated with a water-gate that enables the control of outflowing waters. The hydraulic heads in the low and high permeability matrix are monitored using pressure measurements, and the exchanges are verified using hydrochemical tracers.

\section{Hydrogeological context}

\subsection{Aquifer geometry}


The Coaraze natural laboratory site (Guglielmi and Mudry, 2001), is located in the external Alps of southeastern France, about $30 \mathrm{~km}$ north of Nice (Fig. 2). This site consists of a small natural reservoir (20 m x $15 \mathrm{~m})$ made up of a $15 \mathrm{~m}$ thick pile of fractured Cretaceous limestone, and limited at the bottom and the top by impervious glauconious marl layers (Fig. 2). This small reservoir is fed by water from a fault (see FA in Fig.1b) which has displaced the impermeable layer of the bottom and connects this small aquifer to the regional aquifer.

A detailed description of the Coaraze aquifer fracture network can be found in Cappa et al. (2004). The fracture network of the rock mass is characterized by 26 faults (with a pluri-decametric spatial extention) that extend over the boundaries of the studied reservoir and that spread into three clusters (Fig. 3 a and b):

- 3 faults with a N50 / N70 strike, dipping $70^{\circ}$ to $90^{\circ} \mathrm{SE}\left(\mathrm{F}_{11}, \mathrm{~F}_{12}\right.$ and $\left.\mathrm{F}_{13}\right)$. These faults have a $2-3$ meter spacing - 11 faults with a N120 / N140 strike, dipping $75^{\circ}$ to $90^{\circ} \mathrm{NE}\left(\mathrm{F}_{1}\right.$ to $\mathrm{F}_{10}$ and $\left.\mathrm{F}_{14}\right)$ and with a 2 meter mean spacing - 12 bedding planes with a N40 strike, dipping $45^{\circ} \mathrm{SE}\left(\mathrm{S}_{1}\right.$ to $\left.\mathrm{S}_{12}\right)$ and with spacings ranging between 0.5 and 1 meter.

The fractured calcareous rock mass is drained by a main spring (average yearly yield of $12 \mathrm{Ls}^{-1}$ ) located on a vertical impervious fault between permeable limestones and impervious marls (see FB in Fig. 2b). This fault plays the role of a natural dam for the water which is stored in the reservoir. The spring can be artificially closed with a water-gate; thus the water head in the reservoir is controlled by opening or closing the gate. $30 \mathrm{~m}$ upstream from the water-gate, water originating from a fault flows continuously into the reservoir. The topographic surface of the massif has been rendered waterproof with concrete to a $10 \mathrm{~m}$ height, to prevent water leakages from the aquifer when the water head increases within the rock mass after the closure of the water-gate. When the water-gate is completely closed, the spring does not discharge any more, and the interstitial pressure increases and stabilizes up to $10 \mathrm{~m}$ above the water-gate. Water stored inside the fractures and bedding planes network saturates a volume of reservoir of about $13,500 \mathrm{~m}^{3}$. When interstitial pressure stabilizes, two temporary springs (T1 and T2) overflow at the reservoir boundaries (Fig. 2). When the water-gate is opened, water stored in the reservoir flows out. The hydraulic boundaries of the reservoir are thus well known and can be summarized as follows:

- 4 impervious boundaries corresponding to the top and the bottom geologic layers (impervious marls), the downstream fault and the topographic surface covered with concrete.

- 1 permeable boundary corresponding to the upstream fault.

\subsection{Hydraulic characterisation of the Coaraze dual-permeability aquifer}


Guglielmi and Mudry (2001) and Cappa et al. (2004) studied in detail the hydraulic links between lowpermeability bedding planes and permeable fractures, in order to decipher the dual-permeability processes in the fractured aquifer. These studies highlighted the storage capacity of low-permeability bedding planes in conjunction with the transport capacity of the permeable fractures.

The following hydraulic characteristics of the Coaraze aquifer were thus described by Cappa et al (2004):

- Dual permeability fracture network with highly permeable faults (called F in Fig.3) extending through the whole aquifer thickness and low permeability bedding planes (called S in Fig.3) that consist of a group of 12 discontinuities extending throughout the aquifer thickness.

- High connectivity between the faults and bedding planes.

- The hydraulic conductivity measured with slug tests and injection tests ranges between $5.710^{-5}$ and 2.3 $10^{-4} \mathrm{~ms}^{-1}$ for the fault and between $9.010^{-7}$ and $7.610^{-6} \mathrm{~ms}^{-1}$ for the low-permeability bedding planes.

- The storativity of major faults represents only $4 \%$ of the aquifer total storativity. The remaining $96 \%$ correspond to the storage in the bedding planes (Guglielmi and Mudry 2001).

Guglielmi and Mudry (2001) and Cappa et al. (2004) showed a high permeability contrast between the faults and the bedding planes $\left(\mathrm{K}_{\text {faults }}=100 . \mathrm{K}_{\text {bedding planes }}\right)$. It means that the reservoir is drained by the faults network. The faults represent hydraulic boundaries for the connected bedding planes. Thus it is possible to study in this aquifer the relationship between one fault and the surrounding bedding planes.

\section{Materials and methods}

\subsection{Measurement device}

The different clusters of fractures and bedding planes (Fig. 3a and Fig. 3b) are locally monitored by permanent internal gauges installed in $7 \mathrm{~cm}$ diameter boreholes (Fig. 3c). At each monitoring point, a chamber was cored to enable hydrostatic pressure monitoring in the fracture (Fig. 3d). The pressure measurements are done by interstitial vibrating-wire pressure gauges with an accuracy of $10 \mathrm{~cm}$. Water pressures are referenced to the same elevation origin which corresponds to that of the main spring (water-gate), and represent the hydraulic head. During the experiments, all the measurements are automatically recorded every minute with a data recording station. Ten pressure measurements are carried out in the reservoir on all sets of fractures and bedding planes. In addition to this permanent recording device, a sensor measuring water electrical conductivity and pressure every 30 seconds was installed in the bedding plane (Fig. $3 \mathrm{c}$ ): the pressure was measured with a $1 \mathrm{~cm}$ accuracy 
by a capacitive, oil-free ceramic reference-pressure measuring cell; the temperature was recorded with a $0.1^{\circ} \mathrm{C}$ accuracy by a PT100 sensor; the electrical conductivity was measured with a $0.1 \mu \mathrm{Scm}^{-1}$ accuracy by a WTWTetracon 4-electrode system.

The Water electrical conductivities recorded automatically in the fault (F3) and in the bedding plane are always validated with manual measurements

\subsection{Experimental protocol}

Following one week of water-gate closing (experiment $f_{0}$ ), the experiments consisted of opening and closing the water-gate in order to induce water-table fluctuations in the massif. Figure 4 shows, projected on the same vertical theoretical cross-section, the bedding plane $\left(\mathrm{S}_{2}\right)$ and fault plane $\left(\mathrm{F}_{3}\right)$ which were tested, with the schematic water tables induced during the four experiments $\left(f_{1}, f_{2}, f_{3}, f_{4}\right)$.

The experiment consists of four hydraulic unloadings / loadings, respectively of $10 \mathrm{~min}\left(f_{1}\right), 20 \mathrm{~min}\left(f_{2}\right), 40 \mathrm{~min}$ $\left(f_{3}\right)$ and $40 \min \left(f_{4}\right)$ duration. Each saturation stage of the aquifer is preceded by a drainage stage $d_{1}, d_{2}, d_{3}$ and $d_{4}$ with the same duration as the refilling stage. During the water-gate closures, the water was sampled every minute for the first closure $\left(f_{1}\right)$, every 2 min for the second closure $\left(f_{2}\right)$ and every 4 min for the last closure $\left(f_{3}\right.$ and $f_{4}$ ) at the outlet of $\mathrm{S}_{2}$ (bedding plane) and $\mathrm{F}_{3}$ (fault plane). The notation $\mathrm{F} 3(\mathrm{x})$ means that the water was sampled in the fault $\mathrm{F} 3$ at the $\mathrm{x}^{\text {th }}$ minutes of the experiment.

During the opening of the water-gate, no sampling was done because the water flow from the discontinuities was null.

Water was sampled along the bedding plane $\left(\mathrm{S}_{2}\right)$ and along the fault $\left(\mathrm{F}_{3}\right)$ through two sampling pipes that remained opened during all the experiments. Samples for the major ion analysis were preserved in $50 \mathrm{ml}$ highdensity polyethylene bottles. Before sampling, each bottle was rinsed three times with the sampled water. When the samples were collected, $\mathrm{pH}$, electrical conductivity, and temperature were measured in the field with a WTW portable $\mathrm{pH}$-conductivity meter, calibrated before the experiment. For each collection, three different samples were taken, one for alkalinity, one for major dissolved cations, one for major dissolved anions.

Alkalinity and $\mathrm{Ca}^{2+}$ were measured within the first 12 hours after the campaign, by titration with a potentiometric titration workstation (model TitraLab $90 \AA$, Radiometer Analytical ${ }^{\circledR}$ ); the standard deviation for calcium was given to $\pm 0.005 \mathrm{mmolL}^{-1}$ or $\pm 0.3 \%$ and for alkalinity $\pm 0.007 \mathrm{mmolL}^{-1}$ or $\pm 0.28 \%$. 
The cations $\mathrm{K}^{+}, \mathrm{Na}^{+}, \mathrm{Mg}^{2+}$ were analysed with an atomic absorption spectrophotometer (Perkin Elmer 1100B $($ )). The sensitivity of this instrument for the various cations is as follows: $\mathrm{K}^{+}: \pm 0.02 \mathrm{mmolL}^{-1}, \mathrm{Mg}^{2+}, \pm 0.04 \mathrm{mgL}^{-1}$, $\mathrm{Na}^{+}: \pm 0.005 \mathrm{mgL}^{-1}$

Anions $\mathrm{SO}_{4}{ }^{2-}, \mathrm{NO}^{3-}$ and $\mathrm{Cl}^{-}$were analysed by high-pressure ion chromatography. The chromatograph used was a Dionex DX100® equipped with an automatic sampler. The accuracy is $\pm 0.2 \mathrm{mgL}^{-1}$.

The accuracy of the overall analysis was checked for each sample by calculating a charge balance. All the analyses were performed in the Hydrogeology Laboratory of the Department of Geosciences (University of Franche-Comté).

\section{Results and discussion}

\subsection{Relation between hydrochemical measurements and aquifer rocks.}

The measured concentrations indicate $\mathrm{HCO}_{3}{ }^{-}-\mathrm{Ca}^{2+}-\mathrm{Mg}^{2+}$ water type and the time variations of concentrations are (for more than $80 \%$ ) explained with these three ions (Table 1). During all the experiments, $\mathrm{Ca}^{2+}$ concentrations range from $1.70 \mathrm{mmolL}^{-1}$ to $1.82 \mathrm{mmolL}^{-1}(\Delta=0.12), \mathrm{Mg}^{2+}$ concentrations range from 0.56 mmolL ${ }^{-1}$ to $0.62 \mathrm{mmolL}^{-1}(\Delta=0.06) . \mathrm{HCO}_{3}{ }^{-}$concentrations range from $3.90 \mathrm{mmolL}{ }^{-1}$ to $4.25 \mathrm{mmol} \cdot \mathrm{L}^{-1}(\Delta=0.35)$ and $\mathrm{pH}$ range from 7.61 to 7.7 . Thus despite their closeness (4 meters) and their high-connectivity, water contained in $\mathrm{F}_{3}$ (high permeability) and $\mathrm{S}_{2}$ (low permeability) are chemically different, with a low pH and high bicarbonate content for the bedding plane related to the fault. Table 1 show that the water from the low permeability matrix presents higher electrical conductivity values than the water from the fault.

In this carbonate $\left(\mathrm{CaCO}_{3}\right)$ and dolomite $\left(\mathrm{CaMg}\left(\mathrm{CO}_{3}\right)_{2}\right)$ context, one can assess that carbonate and dolomite dissolution/ precipitation are the two main factors controlling the water chemistry evolution (White, 2002). These dissociation equations are controlled by the $\mathrm{CO}_{2}$ concentration in water (Buhmann and Dreybrodt 1984 , 1985; Dreybrodt and Buhmann, 1992; Liu et al. 1995; Liu and Dreybrodt 1997; Dreybrodt et al., 1997). These reactions can be described with the equations 1,2 and 3

$$
\begin{aligned}
& \mathrm{CaCO}_{3}+\mathrm{H}_{2} \mathrm{O}+\mathrm{CO}_{2}<=>2 \mathrm{HCO}_{3}^{-}+\mathrm{Ca}^{2+} \\
& \mathrm{CaMg}\left(\mathrm{CO}_{3}\right)_{2}+2 \mathrm{H}_{2} \mathrm{O}+2 \mathrm{CO}_{2}<=>\mathrm{Ca}^{+2}+\mathrm{Mg}^{+2}+4 \mathrm{HCO}_{3}^{-} \\
& \mathrm{CO}_{2}(\mathrm{~g})+2 \mathrm{H}_{2} \mathrm{O} \Leftrightarrow=\mathrm{HCO}_{3}^{-}+\mathrm{H}_{3} \mathrm{O}^{+}
\end{aligned}
$$

Based on the concentration measurements, the saturation indexes for these three reactions were calculated, with the PHREEQC software and its database for equilibrium constant and water activity calculations (Table 1). 
At the scale of the three experiments, the waters are close to the equilibrium versus dolomite (saturation index values between -0.01 and 0.1 ) and slightly oversaturated versus calcite (saturation index values between 0.24 and 0.29). This calculation is coherent with the relative stability of the $\mathrm{Ca}$ and $\mathrm{Mg}$ measured concentrations. The water is close to equilibrium and no reaction between water and calcite / dolomite minerals is considered in the duration of the experiments.

\subsection{Water chemistry evolution related to water-table fluctuations.}

Although no water / rock interaction is observed, the electrical conductivities recorded at the outlet of the bedding plane $\left(\mathrm{S}_{2}\right)$ and at the outlet of the fault $\left(\mathrm{F}_{3}\right)$ display an evolution with the closures / openings of the water-gate (Fig. 5). The conductivity measured in the fault ranged from $436 \mu \mathrm{Scm}^{-1}$ to $443 \mu \mathrm{Scm}^{-1}$; the conductivity measured in the bedding plane ranged from $457 \mu \mathrm{Scm}^{-1}$ to $439 \mu \mathrm{Scm}^{-1}$ (Fig. 5).

The $\mathrm{pH}$ and bicarbonate concentration evolved (Fig.6) during the experiment. The minimum and maximum values are observed during stabilized low water table. The minimum $\mathrm{HCO}_{3}{ }^{-}$values are about $3.9 \mathrm{mmolL}^{-1}$ and 7.7 for the $\mathrm{pH}$ in the drained permeable fault $\left(\mathrm{t}_{0}\right)$. The maximum values are about $4.25 \mathrm{mmolL}^{-1}$ and 7.61 , respectively, and appear to be measured in the bedding plane $\mathrm{S}_{2}$ after the stabilized drainage stage $\left(\mathrm{S}_{2}\left({ }_{(90)}\right)\right.$.

\section{3. $\mathrm{CO}_{2}$ dissolution in the low permeability matrix.}

Water contained in the low permeability matrix shows low $\mathrm{pH}$ and high $\mathrm{HCO}_{3}$ values compared to water from the fault. The conductivity increase of $10 \mu \mathrm{Scm}^{-1}$ (Fig. 5) is correlated with a $0.3 \mathrm{mmolL}^{-1} \mathrm{HCO}_{3}$ increase and $0.25 \mathrm{pH}$ decrease and may result from the perturbation of the $\mathrm{H}_{2} \mathrm{O}-\mathrm{CO}_{2}-\mathrm{CaCO}_{3}$ equilibrium.

During the draining stages, if the bedding plane had been dry, the probe would have recorded a null electrical conductivity value. No null values were observed so the bedding plane was never totally dry. In these conditions, where hydraulic head is null, one can assess that the bedding plane is not saturated, which may have enabled the possible arrival of air. In this hypothesis $\mathrm{CO}_{2 \mathrm{gas}}$ is dissolved in $\mathrm{CO}_{2 \mathrm{aq}}$, and allows the water to take $\mathrm{HCO}_{3}{ }^{-}$ions and protons into solution, according to equation 3. Electrical conductivity increase is induced by the $\mathrm{HCO}_{3}{ }^{-}$ concentration increasing in the bedding plane. The water recorded a new $\mathrm{CO}_{2}$ stock arrival in the low permeability matrix (Fig.8a). As explained by some authors (Dreybrodt and Buhmann, 1991; Dreybrodt et al. 1996, Fourar and Bories, 1999) this reaction could be very rapid in carbonated aquifers, as a function of hydraulic parameters and physicochemical parameters. Here, electrical conductivity curves show an increase during draining, about 10 minutes before the stabilization. 


\subsection{Cumulative evolution of water chemistry during successive water-table fluctuations}

When the refilling is done, the electrical conductivities, the $\mathrm{pH}$ and the bicarbonates measured in the fault and in the joint are stabilized around an intermediate value (noted P1, P2, P3 and P4 in Fig.6). The different volumes of water from low and high permeability discontinuities become mixed. It appears that the stabilisation point of the bicarbonates for the bedding plane and the fault is evolved from $f_{1}$ to $f_{4}$ so $P_{1}<P_{2}<P_{3}<P_{4}$ (Fig. 6).

The upward evolution of the stabilisation point of the bicarbonates reveals a modification created by the cumulative draining/ refilling stages (Fig.6). This evolution is correlated with a downward evolution of the $\mathrm{pH}$.

This increased cumulative modification may be the result of $\mathrm{CO}_{2}$ dissolution capacity that increases with the desaturation of the low permeability matrix, created by the successive draining phase. The contrast between water chemistry in low and high permeability matrices increases during the experiments.

\subsection{Influence of the saturation state on the bicarbonates acquisition.}

During draining stages, water sampling is impossible without modification of the head in the low permeability matrix. However, the no-null and increasing electrical conductivity values (see $\mathrm{d}_{1}, \mathrm{~d}_{2}, \mathrm{~d}_{3}, \mathrm{~d}_{4}$ in Fig.5) inform about water chemistry evolution during draining stages. The increase of the bicarbonates concentrations observed between the initial stage before opening $\mathrm{F} 3_{(60)}$ and the final stage just after the closure $\mathrm{S} 2_{(90)}$ of the water-gate is an indirect monitoring of bicarbonates acquisition in unsaturated conditions.

Two cases are distinguished, related to the monitored hydraulic heads in the low permeability matrix.

In the first case, the hydraulic head in the bedding plane $S_{2}$ equals 0 after a 5 min delay after the water-gate opening $d_{2}$ (Fig. 7). An increase of electrical conductivity from $441 \mu \mathrm{Scm}^{-1}$, to reach a stabilisation at $459 \mu \mathrm{Scm}^{-1}$ is recorded.

In the second case $\left(d_{3}\right)$, a residual hydraulics heads of about $0.2 \mathrm{~m}$ is maintained along the bedding plane with the water-gate (Fig. 7). In this case, the water electrical conductivity increases but to a lesser extent than in the first case, and stabilizes more rapidly at a value of $444 \mu \mathrm{Scm}^{-1}$. The maximum that the electrical conductivity reaches is controlled by residual hydraulic heads in the bedding plane (Fig.7).

The increase of electrical conductivity during draining stage is attributed to the bicarbonate acquisition induced by the $\mathrm{CO}_{2}(\mathrm{~g})$ dissolution. Thus when the bedding plane recorded low hydraulic head, the bedding plane is fully unsaturated and the bicarbonates acquisition is maximum. The residual hydraulic head informs about the degree of (un)saturation of the bedding plane and controls the amount of dissolved $\mathrm{CO}_{2}$. 


\subsection{Differentiation of the water chemistry controlled by the permeability.}

After long (one week $\mathrm{f}_{0}$ ) high water levels in the aquifer, the samples taken show a differentiation of the water chemistry stored in the bedding plane $\left(\mathrm{S}_{2(0)}\right)$ compared to the water sampled in the fault $\left(\mathrm{F}_{3(0)}\right)$ (Table 1$)$. This indicates a renewal of water in the permeable faults which is more important than in the low-permeability bedding plane. During the one week saturation, water contained in the low-permeability matrix remained isolated from water which flows in the faults (Fig.8b). The chemistry of the water in $F_{3(0)}$ can be considered as representative of the water from the upstream (Table 1).

After long low water levels a chemical differentiation is also observed, with high $\mathrm{HCO}_{3}{ }^{-}$and low $\mathrm{pH}$ in the bedding plane, illustrated by the difference between the samples $\mathrm{S}_{2(40)}$ and $\mathrm{F}_{3(40)}$ or $\mathrm{S}_{2(90)}$ and $\mathrm{F}_{3(90) \text {. }}$

The hydrochemical evolution of water along the permeable fault is limited because of the permanent water renewal and because the water keeps its low bicarbonate characteristic. The hydrochemical evolution of water along the bedding plane located in the saturated / unsaturated interface shows an increase in the bicarbonate concentration and a decrease in $\mathrm{pH}$ value in less than $10 \mathrm{~min}$. This hydrochemical differentiation can be used as a tracer of exchanges between the fault and the variably saturated low-permeability matrix.

\subsection{Water mixing induced by hydraulic head gradient fluctuations.}

The intermediate $441 \mu \mathrm{Scm}^{-1}$ value, and all the $\mathrm{P}_{1}, \mathrm{P}_{2}, \mathrm{P}_{3}$ and $\mathrm{P}_{4}$ stabilization points (Fig.5 and 6) show that water in the unsaturated bedding plane flows towards the fault, and that water from the fault refilled the bedding plane. Waters from the discontinuities of different permeabilities are mixed. The low-permeability matrices contributed to the refilling of the permeable faults, and to mixing of the waters (Fig.8c) independently of the regional hydraulic gradient.

During the mixing, electrical conductivities in the bedding plane presented variable responses related to the hydraulic heads :

In the first case, before closure, the hydraulic heads in the fault and in the bedding plane are null (residual hydraulic head is about $0.05 \mathrm{~m}$ for $d_{2}$ ). When the hydraulic head increases in the fault and more slowly in the bedding plane, the conductivity falls immediately, reaches an intermediate value of $441 \mu \mathrm{Scm}^{-1}$ again after 10 min, and remains stable until the next event (Fig. 5 and 7).

In the second case, a residual hydraulic head about $0.2 \mathrm{~m}$ is recorded when the water-gate is closed. $2 \mathrm{~min}$ after the water-gate closure, a $10 \mu \mathrm{Scm}^{-1}$ peak is recorded, then the conductivity again reaches $441 \mu \mathrm{Scm}^{-1}$ (for 
example in the drainage phase $\mathrm{d}_{3}$ ). The hydraulic head rise in the fault which bounds the bedding plane induces a dynamic flow in the bedding plane which expels water contained in the bedding plane.

The electrical conductivity peaks (Fig. 5 and 7) are the result of a piston effect induced by a hydraulic head variation which occurs in the low permeability zones of the aquifer and suggest a heterogeneous bedding plane surface. It can be explained by the roughness of the plane (Halihan et al. 1998; Aydin 2001). This confirms the hydraulic model previously proposed (Guglielmi and Mudry 2001). During an aquifer refilling, the highly conductive faults are refilled partly by water coming from low-permeability matrices with variable flow rates.

\subsection{Consequences for a better understanding of hydrochemical measurements realised at karst springs draining} regional aquifers

During high water-table levels, water contained in the low-permeability matrix is stored. Water which flows in permeable zones is continuously renewed. The chemical evolution of water is limited. If this high water-table stage is interrupted by a low water-table period, hydraulic head in high-permeability faults decreases, but lowpermeability media are not directly affected by this hydraulic head decrease. Water from low-permeablility media contribute to feed the permeable fault. This mechanism contributes to the mineralization increase recorded at karst springs during low water levels.

. In the unsaturated zone, water is stored in the low-permeability matrix but in less proportion than in the saturated zone, and the two-phase water/air flow induces a mineralization increase more important than in saturated volumes with short time duration.

During the subsequent aquifer recharge, water inflow coming from permeable regions will contribute to refilling a part of the low-permeability ones but, at the same time, the low-permeability matrices refill the permeable ones. This mechanism could be the cause of the peak of mineralization increase recorded in some karst springs at the beginning of flood events and could explain the (re)mobilization of pollutants stored in the low permeability matrices when the water table is rising.

\section{Conclusions}

In aquifers with a large range of permeabilities, the water exchanges between high and low permeability regions are controlled by hydraulic head gradient. Previous studies addressed this problem at the scale of large aquifers 
during steady state conditions. This work, undertaken at the meso-scale (10m x 10m x 10m) in the small Coaraze aquifer, with the help of hydrochemical tracing, allows for the precise characterization of hydraulic relations between low and high permeability features of a fractured aquifer, at the scale of a group of discontinuities under experimentally induced water-table fluctuations.

In this carbonate aquifer no water/rock interactions are identified. However, evolution of the water chemistry is observed in the low permeability matrices located at the saturated / unsaturated interface. With successive and quick water-table fluctuations, the global mineralization and $\mathrm{pH}$ decrease, but the bicarbonate content increases, related to gas carbon dioxide dissolution. At the scale of a group of rock discontinuities, a chemical signature in groundwater was identified related to the permeability of the reservoir.

During hydraulic head fluctuations, the different volumes of water from low and high permeability discontinuities become mixed. During water-table rises, the low-permeability regions contributed to the refilling of the permeable faults and to the mixing of the waters. At the same time, flows opposite to the hydraulic gradient expelled highly mineralized water towards the spring. This mechanism could be the origin of the peak in mineralisation recorded in some karst springs at the start of flood events.

This work highlights the sensitivity of hydrochemistry in characterising the mixing process, while hydraulic measurements do not provide the same accuracy. These results have a direct application in water management, notably in the knowledge of the mechanisms that control (re)mobilization of pollutants in a fractured aquifer during water-table fluctuations.

Acknowledgements. Dr Mettetal of the DIREN Franche-Comté provided financial support for the study. We thank Hydrogeology Journal's Associate Editor and the two reviewers of this paper. 


\section{References.}

Aydin A (2001). Fracture void structure: implications for flow transport and deformation. Environmental Geology vol. 40: pages 672-677.

Buhmann D and Dreybrodt W (1984). The kinetics of calcite dissolution and precipitation in geologically relevant situations of karst areas *1: 2. Open System. Chemical Geology 48: 189-211.

Buhmann D and Dreybrodt W (1985). The kinetics of calcite dissolution and precipitation in geologically relevant situations of karst areas *2: 2. Closed system. Chemical Geology 53: 109-124.

Cappa F, Guglielmi Y, Fenart P., Merrien-Soukatchoff V and Thoraval A (2004) Hydromechanical interactions in a fractured carbonate reservoir inferred from hydraulic and mechanical measurements International Journal of Rock Mechanics and Mining Sciences.

Dreybrodt W and Buhmann D (1991). A mass transfer model for dissolution and precipitation of calcite from solutions in turbulent motion. Chemical Geology 90: 107-122.

Dreybrodt W, Buhmann D, Michaelis J and Usdowski E (1992). Geochemically controlled calcite precipitation by $\mathrm{CO}_{2}$ outgassing: Field measurements of precipitation rates in comparison to theoretical predictions. Chemical Geology 97: 285-294.

Dreybrodt, W, Lauckner J, Zaihua, L, Svensson, U \& Buhmann, D (1996). The kinetics of the reaction $\mathrm{CO}_{2}+$ $\mathrm{H}_{2} \mathrm{O}->\mathrm{H}^{+}+\mathrm{HCO}_{3}^{-}$as one of the rate limiting steps for the dissolution of calcite in the system $\mathrm{H}_{2} \mathrm{O}---$

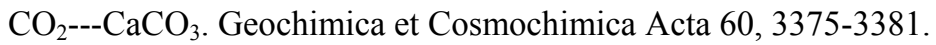

Dreybrodt W, Eisenlohr L, Madry B and Ringer S (1997). Precipitation kinetics of calcite in the system $\mathrm{CaCO}_{3}^{-}-$ $-\mathrm{H}_{2} \mathrm{O}---\mathrm{CO}_{2}$ : The conversion to $\mathrm{CO}_{2}$ by the slow process $\mathrm{H}++\mathrm{HCO}_{3}{ }^{-}->\mathrm{CO}_{2}+\mathrm{H}_{2} \mathrm{O}$ as a rate limiting step. Geochimica et Cosmochimica Acta 61: 3897-3904.

Fourar M and Bories S (1999). Experimental study of air-water two-phase flow in a fracture network. Comptes 
Rendus de l'Academie des Sciences - Series IIB - Mechanics-Physics-Chemistry-Astronomy 327: 765 770.

Guglielmi Y and Mudry J (2001). Quantitative Measurement of channel-Block Hydraulic Interaction by experimental saturation of a large, Natural, Fissured Rock Mass. Ground Water Vol. 39(No. 5): 696701.

Halihan T, Wicks CM and Engeln JF (1998). Physical response of a karst drainage basin to flood pulses: example of the Devil's Icebox cave system (Missouri USA). Journal of Hydrology 204: 24-36.

Hinds JJ, Bodvarsson, GS and Nieder-Westermann GH, (2003). Conceptual evaluation of the potential role of fractures in unsaturated processes at Yucca Mountain. Journal of Contaminant Hydrology, 62-63: 111132.

Jeannin P and Grasso AD (1995), Recharge respective des volumes de roche peu perméable et des conduits karstiques, rôle de l'épikarst [Low permeability rock and karstic drains recharge, the epikarst role], Bulletin d'hydrogéologie, 14, 95-111.

Kiraly L (1969) Anisotropie et hétérogénéité de la perméabilité dans les calcaires fissurés [Permeability anisotropy and heterogeneity in fractured limestones]. Eclogae geologicae Helvetiae, 62, 613-619.

Lee ES and Krothe NC (2003). Delineating the karstic flow system in the upper Lost River drainage basin south central Indiana: using sulphate and ${ }^{34} \mathrm{~S} \mathrm{SO}_{4}$ as tracers. Applied Geochemistry 18: 145-153.

Liu Z. and Dreybrod W. (1997). Dissolution kinetics of calcium carbonate minerals in $\mathrm{H}_{2} \mathrm{O}---\mathrm{CO}_{2}$ solutions in turbulent flow: The role of the diffusion boundary layer and the slow reaction $\mathrm{H}_{2} \mathrm{O}+\mathrm{CO}_{2}->\mathrm{H}^{++}$ $\mathrm{HCO}_{3}{ }^{-}$. Geochimica et Cosmochimica Acta 61: 2879-2889.

Maloszewski P, Stichler W, Zuber A and Rank D (2002). Identifying the flow systems in a karstic-fissuredporous aquifer the Schneealpe Austria by modelling of environmental ${ }^{18} \mathrm{O}$ and ${ }^{3} \mathrm{H}$ isotopes. Journal of 
Hydrology 256: 48-59.

Martin JB and Dean RW (2001). Exchange of water between conduits and matrix in the Floridian aquifer. Chemical Geology 179: 145-165.

Rutqvist J (1995). Determination of hydraulic normal stiffness of fractures in hard rock from well testing. Int. J. Rock. Mech. Min. Sci. \& Geomech. Abstr. 32: 513-523.

Sauter M (1992). Quantification and forecasting of regional groundwater flow and transport in a karst aquifer (Gallusquelle Malm SW Germany). Tubinger Geowissenschaftliche Arbeiten Part C 13: 151.

Teutsch G and Sauter M (1991). Groundwater modeling in karst terranes: scale effects data acquisition and field validation. Proceedings of the Third Conference on Hydrogeology Ecology Monitoring and Management of Ground Water in Karst Terranes Nashville TN: 17-35.

White WB (2002). Karst hydrology: recent developments and open questions. Engineering Geology 65: 85-105. 
Figure captions:

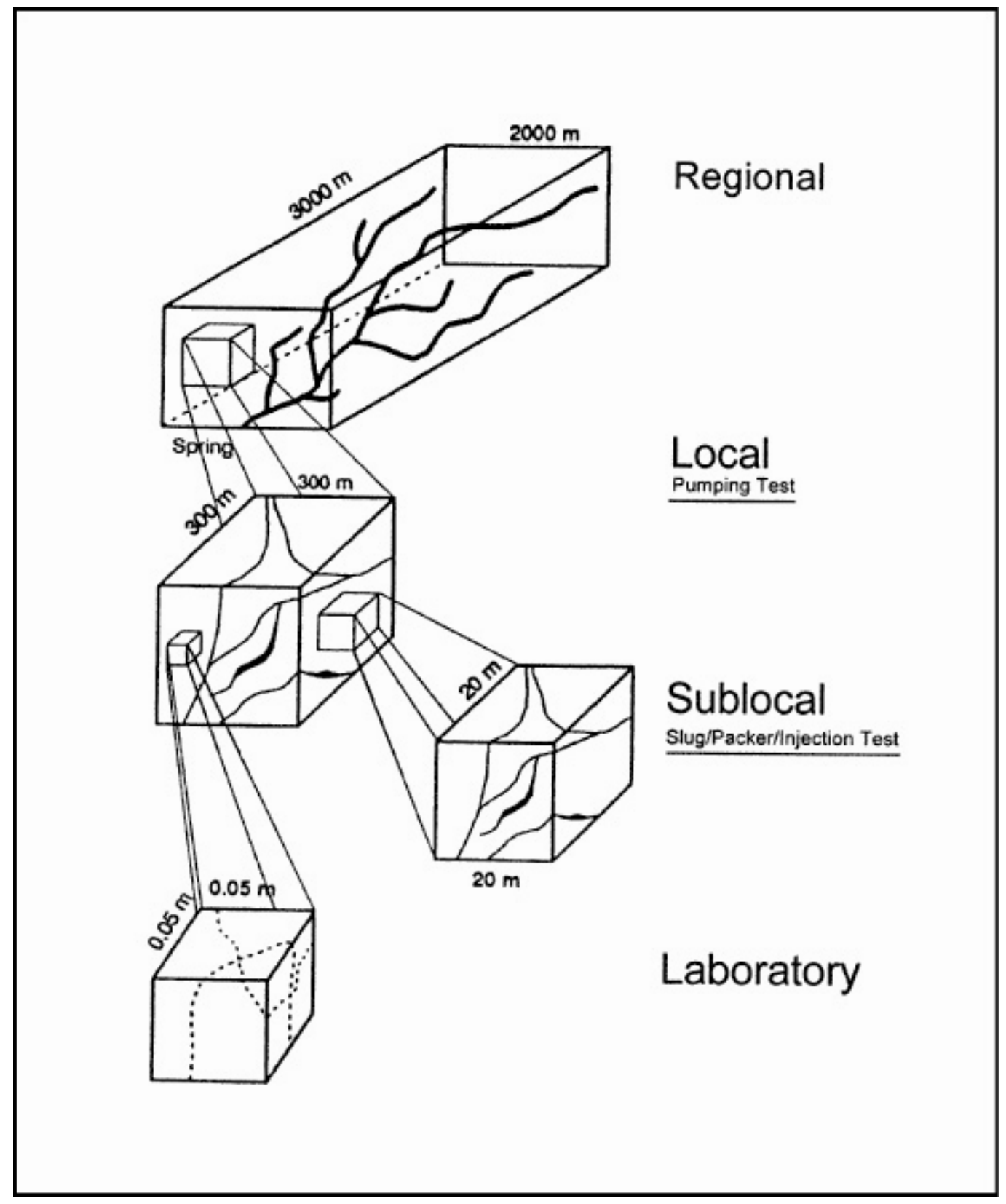

Figure 1: Scales used in scale-dependant permeability studies in karst aquifers (after Kiraly 1968, White 2002). 


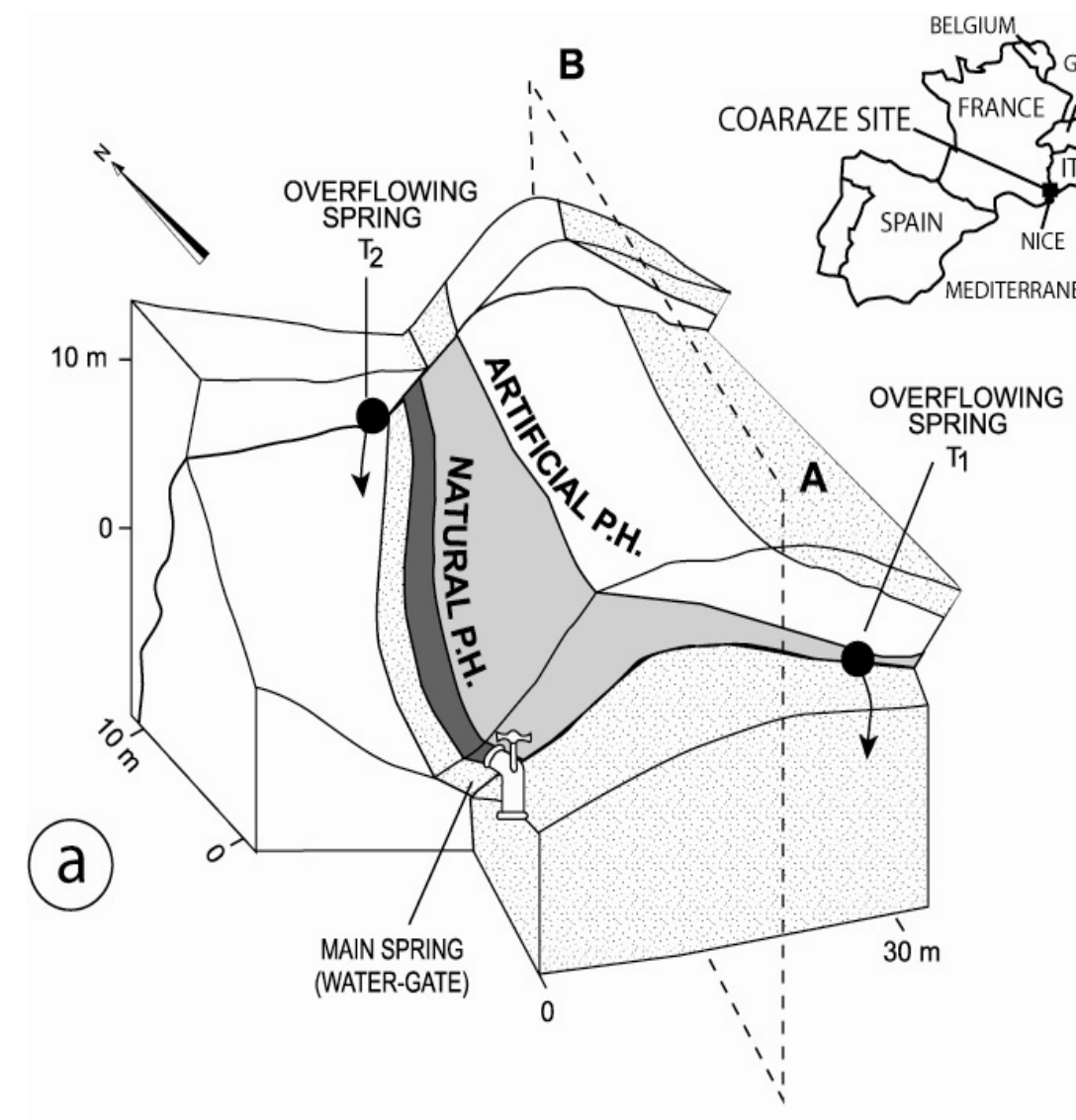

B

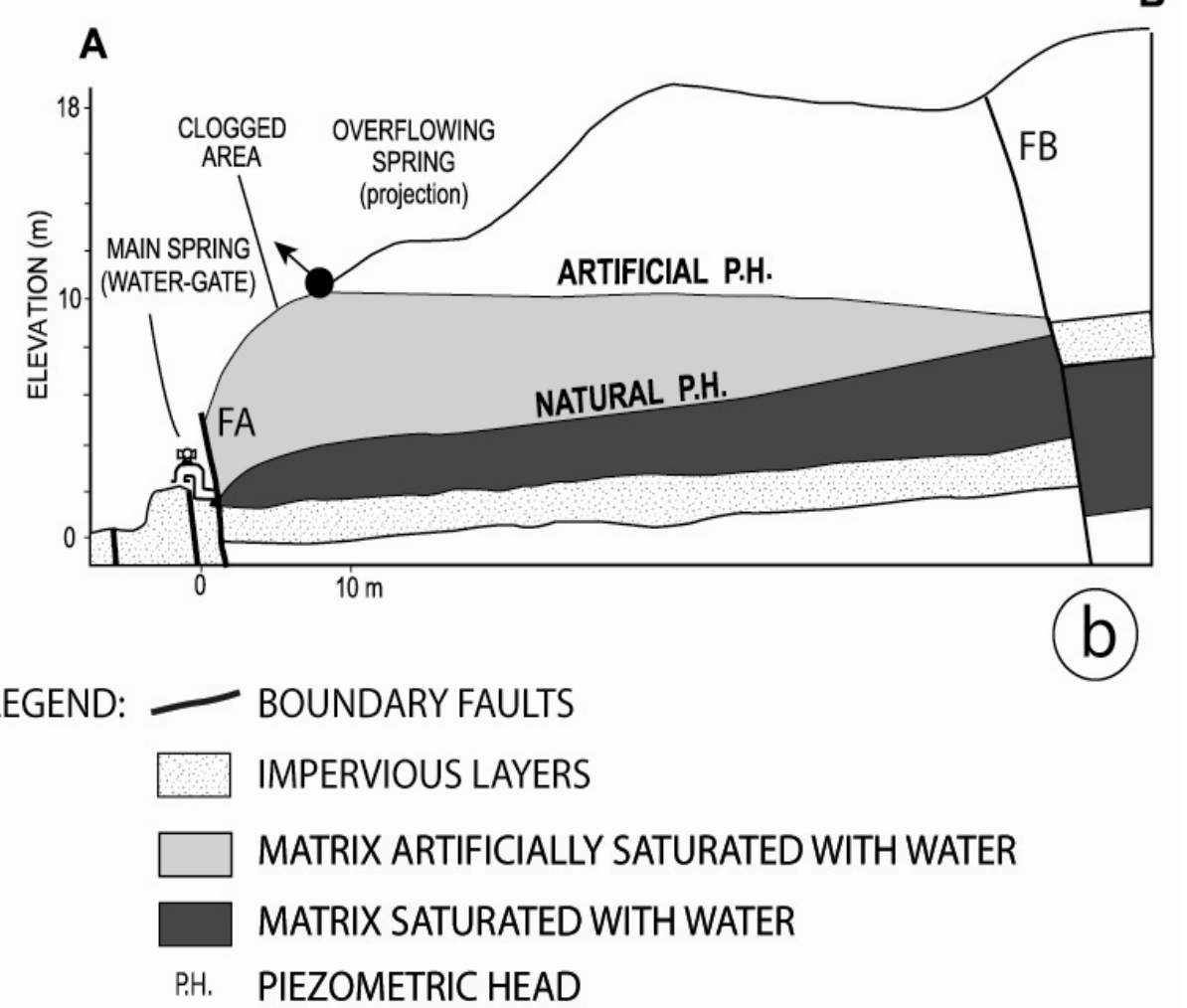

Figure 2: Hydrogeological context of the Coaraze experimental aquifer - (a) 3-dimensional (3D) view- (b) Longitudinal cross section (after Cappa et al., 2004). Elevation (m) is relative to the main spring elevation. 

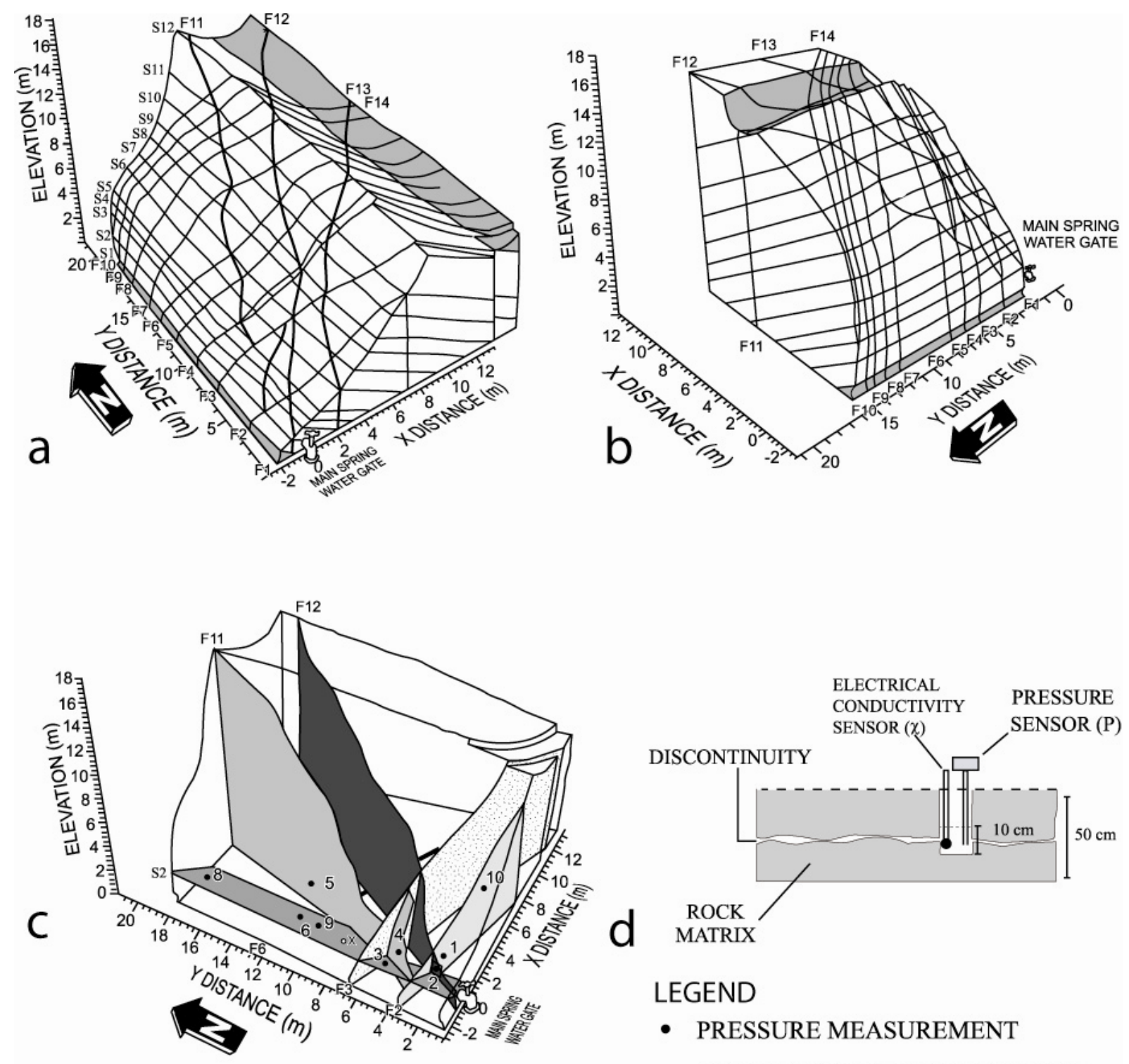

- PRESSURE MEASUREMENT

PRESSURE AND PHYSICO-CHEMICAL

- MEASUREMENTS

F6 F1 TO F14 FAULTS

S2 S1 TO S12 BEDDING PLANES

Figure 3: (a)-(b) 3D geometrical model of fractures of the Coaraze aquifer, viewed from two angles.- (c) experimental device- (d) Pressure and physico-chemical measurement device at the single bedding planes scale (after Cappa et al., 2004) 


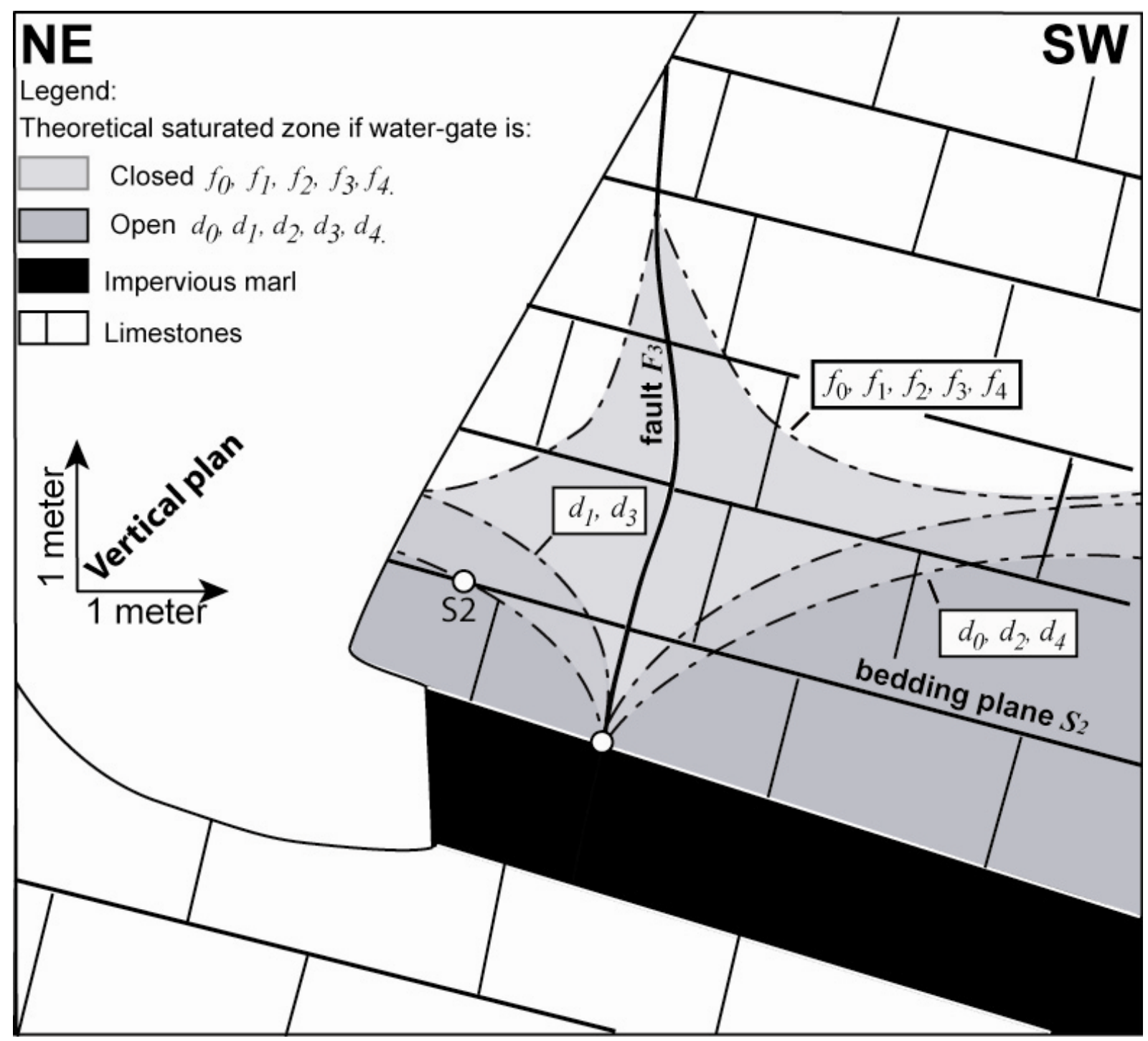

Figure 4: Theoretical vertical cross-section of the reservoir and experimental setting of the experiment. Location of the physico-chemical sampling points in bedding plane $S_{2}$ and in permeable fault $F_{3}$. Grey color is for the theoretical saturated zones, dashed lines for water tables inferred by variable water-gate opening : during the $\mathrm{d}_{0}$ and $d_{2}$ period, the water-gate is fully open; during $d_{1}$ and $d_{3}$ a residual hydraulic head is maintained; during $f_{0}, f_{1}$, $\mathrm{f}_{2}, \mathrm{f}_{3}$, and $\mathrm{f}_{4}$ the water-gate is closed. 


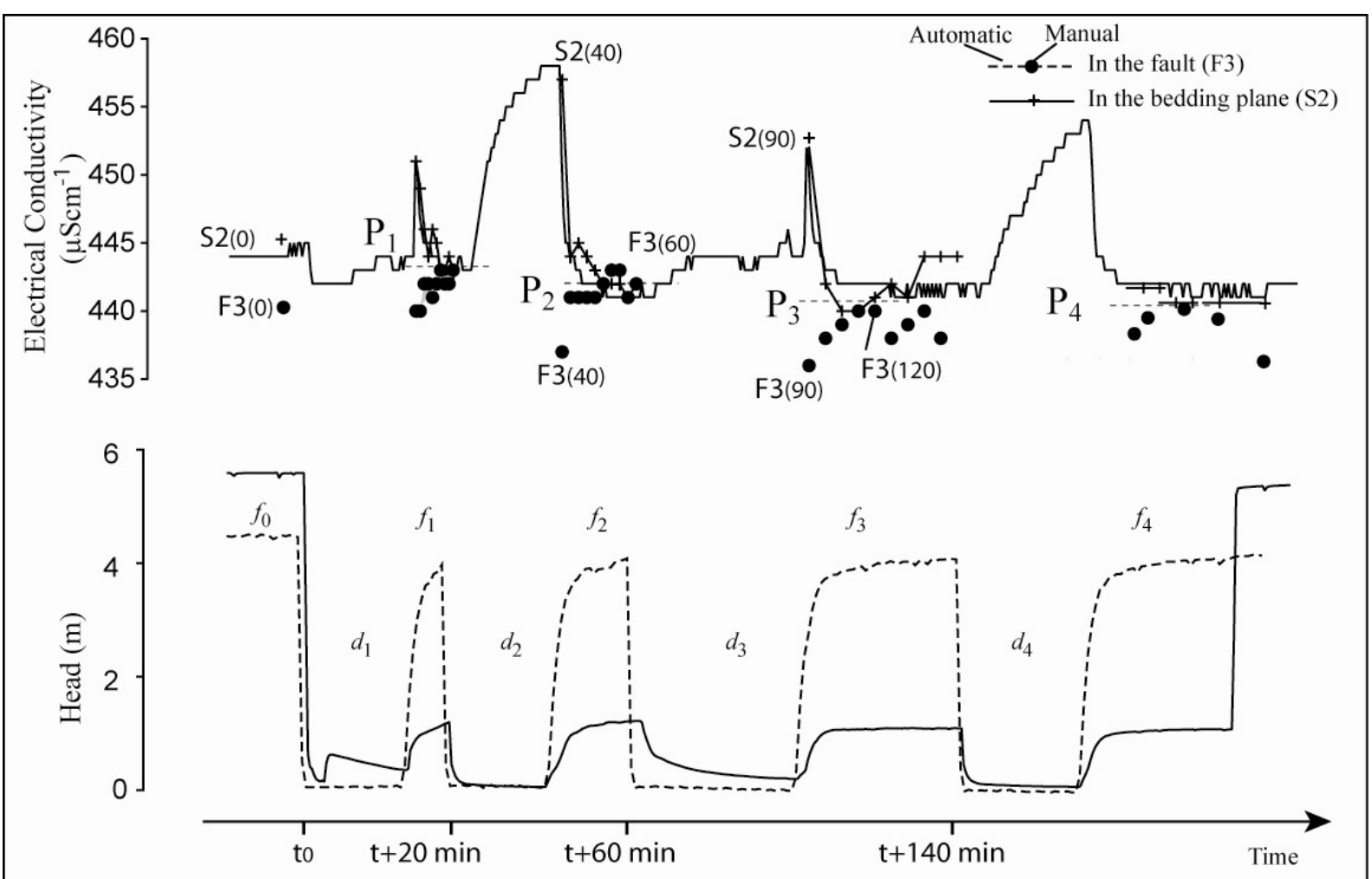

Figure 5: Hydraulic head evolution through time in $\mathrm{S}_{2}$ and $\mathrm{F}_{3}$, and automatic and manual electrical conductivity records through time in $S_{2}$ and $F 3$ during refilling phases $f_{0}, f_{1}, f_{2}, f_{3}, f_{4}$ and draining phase $d_{1}, d_{2}, d_{3}, d_{4} . P_{1}, P_{2}, P_{3}$ and $\mathrm{P}_{4}$ are electrical conductivity stabilisation points in the bedding planes and the fault for $f_{1}, f_{2}, f_{3}, f_{4}$ respectively. $\mathrm{F}_{3(\mathrm{x})}$ and $\mathrm{S}_{2(\mathrm{x})}$ are the samples take respectively in the fault and in the bedding plane at the time $\mathrm{x}$ (in minutes) from the first opening. These chemical analyses are presented in Table 1. 


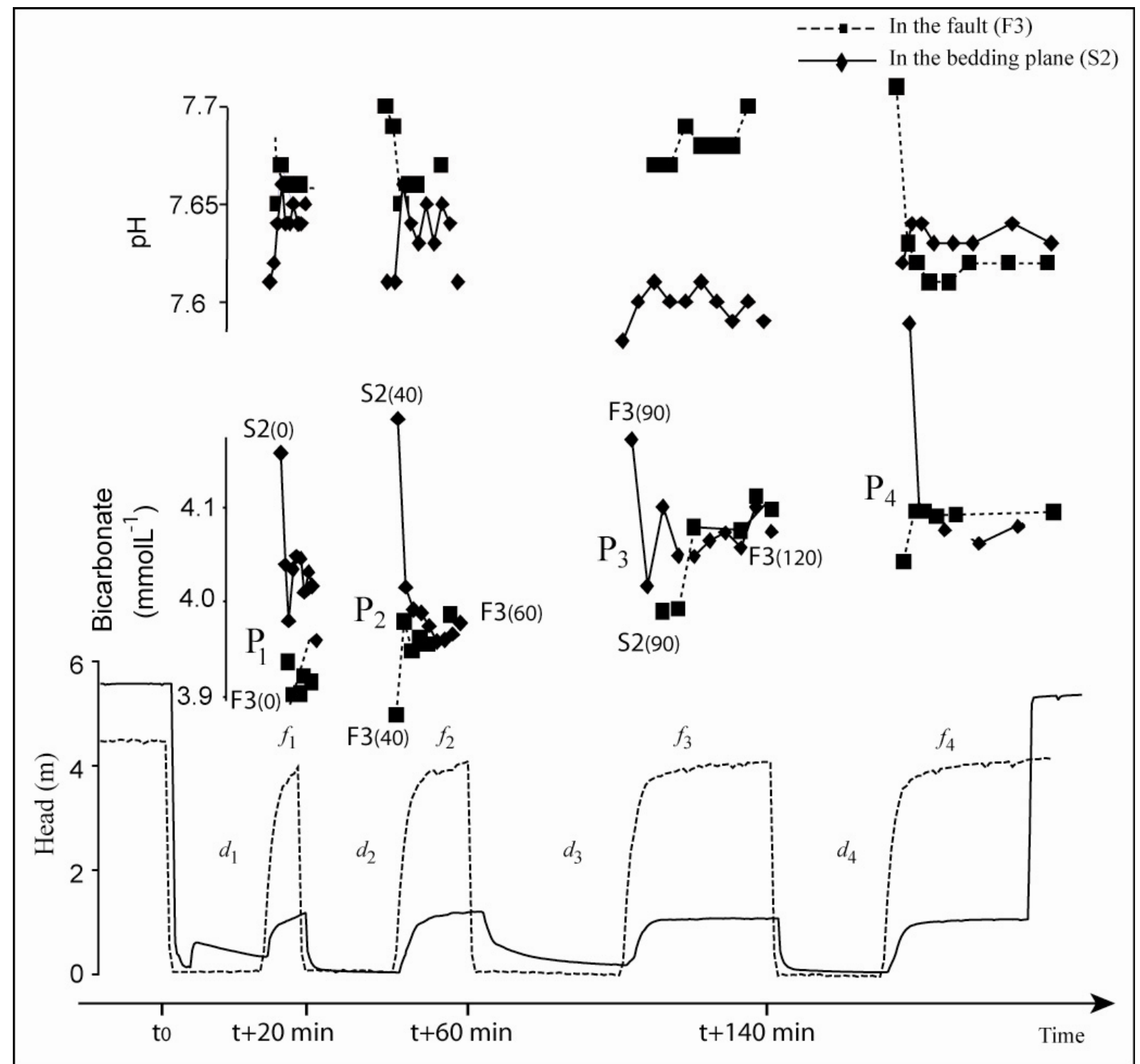

Figure 6: Hydraulic head, bicarbonate and $\mathrm{pH}$ evolution through time in $\mathrm{S}_{2}$ and $\mathrm{F}_{3}$. See Figure 5 caption for explanation. 


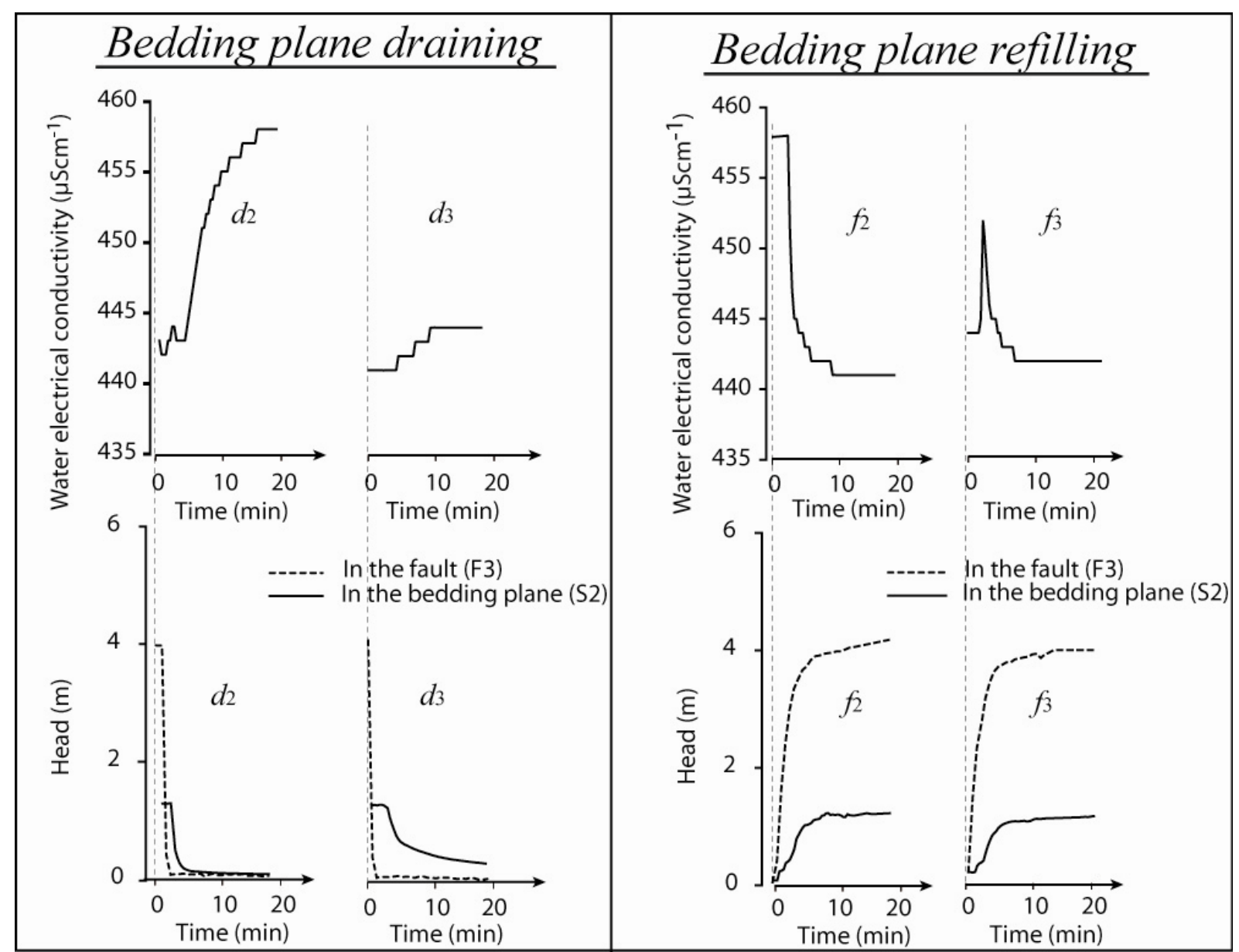

Figure 7: -Water electrical conductivity in $S_{2}$ compared to hydraulic head recorded in the bedding plane $\left(\mathrm{S}_{2}\right)$ and in the fault $\left(\mathrm{F}_{3}\right)$ during aquifer draining $d_{2}$ and $d_{3}$ and during aquifer refilling $f_{2}$ and $f_{3}$. (Automatic conductivity record). 


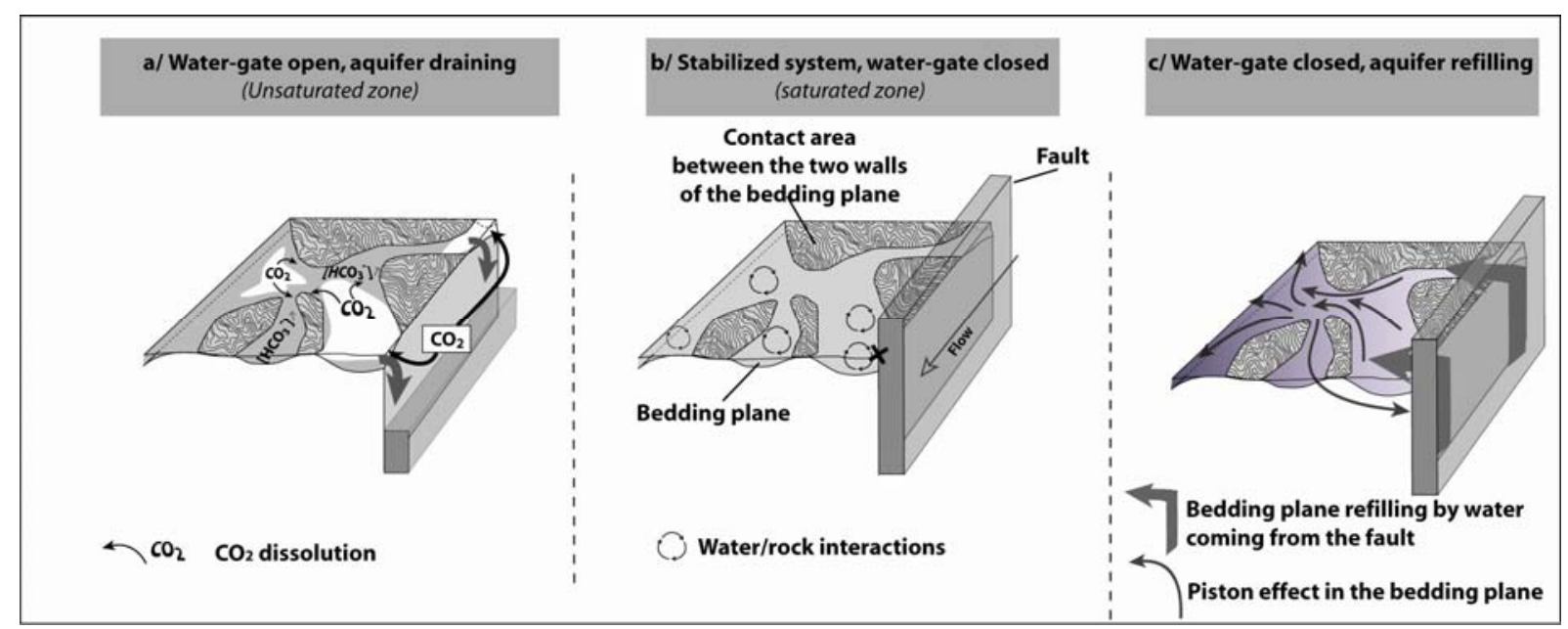

Figure 8: Conceptual model of hydrochemical mixing and reactions of the couple fault/bedding plan as a function of hydraulic head variations in the Coaraze aquifer, deduced from hydrochemical experiments realized at the metric scale - (A) Hydrochemical evolution of the couple fault/bedding plane during aquifer draining - (B) Hydrochemical evolution of the couple fault/bedding plane during stabilized water-gate closing - (C) Hydrochemical evolution of the couple fault/bedding plane during aquifer refilling. 


\begin{tabular}{|c|c|c|c|c|c|c|c|c|c|}
\hline & Units & $F_{3}(0)$ & $F_{3}(40)$ & $F_{3}(60)$ & $F_{3}(90)$ & $F_{3}(120)$ & $\mathrm{S}_{2(0)}$ & $S_{2(40)}$ & $S_{2(90)}$ \\
\hline $\mathbf{p H}$ & & 7,7 & 7,7 & 7,67 & 7,7 & 7,65 & 7,61 & 7,61 & 7,61 \\
\hline Cond (automatic) & $\mu \mathrm{S} / \mathrm{cm}$ & 441 & 436 & 442 & 436 & 437 & 445 & 456 & 453 \\
\hline $\mathbf{T}(\mathrm{Wa})$ & ${ }^{\circ} \mathrm{C}$ & 14,1 & 13 & 13,1 & 13 & 14,2 & 13,3 & 12,2 & 12,2 \\
\hline $\mathrm{Ca}^{2+}$ & $\mathrm{mmol} / \mathrm{L}$ & 1,70 & 1,76 & 1,77 & 1,76 & 1,80 & 1,78 & 1,82 & 1,82 \\
\hline $\mathrm{Na}^{+}$ & $\mathrm{mmol} / \mathrm{L}$ & 0,07 & 0,08 & 0,08 & 0,08 & 0,08 & 0,08 & 0,08 & 0,08 \\
\hline $\mathbf{K}^{+}$ & $\mathrm{mmol} / \mathrm{L}$ & 0,02 & 0,02 & 0,02 & 0,02 & 0,02 & 0,02 & 0,02 & 0,02 \\
\hline $\mathrm{Mg}^{2+}$ & $\mathrm{mmol} / \mathrm{L}$ & 0,60 & 0,58 & 0,58 & 0,58 & 0,56 & 0,62 & 0,61 & 0,61 \\
\hline $\mathrm{HCO}_{3}^{-}$ & $\mathrm{mmol} / \mathrm{L}$ & 3,90 & 3,91 & 4,00 & 3,91 & 4,10 & 4,25 & 4,16 & 4,16 \\
\hline $\mathbf{F}$ & $\mathrm{mmol} / \mathrm{L}$ & 0,00 & 0,01 & 0,01 & 0,01 & 0,01 & 0,00 & 0,01 & 0,01 \\
\hline $\mathrm{Cl}^{-}$ & $\mathrm{mmol} / \mathrm{L}$ & 0,06 & 0,07 & 0,07 & 0,07 & 0,07 & 0,06 & 0,08 & 0,08 \\
\hline $\mathrm{NO}_{3}$ & $\mathrm{mmol} / \mathrm{L}$ & 0,01 & 0,01 & 0,01 & 0,01 & 0,01 & 0,01 & 0,01 & 0,01 \\
\hline $\mathrm{SO}_{4}{ }^{2-}$ & $\mathrm{mmol} / \mathrm{L}$ & 0,29 & 0,39 & 0,35 & 0,39 & 0,31 & 0,28 & 0,37 & 0,37 \\
\hline SI Calcite & & 0,27 & 0,29 & 0,27 & 0,29 & 0,29 & 0,26 & 0,25 & 0,24 \\
\hline SI Dolomite & & 0,01 & 0,10 & 0,01 & 0,05 & 0,05 & 0,04 & 0,01 & $-0,01$ \\
\hline $\mathrm{SI} \mathrm{CO}_{2(\mathrm{~g})}$ & & $-2,37$ & $-2,4$ & $-2,37$ & $-2,41$ & $-2,33$ & $-2,27$ & $-2,28$ & $-2,27$ \\
\hline$($ Cat- $\mid$ An $\mid) /($ Cat $+\mid$ An $\mid)$ & $\%$ & $2 \%$ & $0 \%$ & $0 \%$ & $0 \%$ & $0 \%$ & $0 \%$ & $0 \%$ & $0 \%$ \\
\hline
\end{tabular}

Table 1: Concentration of ions in water in the fault $\left(\mathrm{F}_{3}\right)$ and in the bedding plane $\left(\mathrm{S}_{2}\right)$ during the draining refilling experiments, sampled at $\mathrm{t}=0,40,60,90,120 \mathrm{~min}$. 